\title{
What's next? The release of exotic pets continues virtually unabated 7 years after enforcement of new legislation for managing invasive species
}

\author{
Alberto Maceda-Veiga (1) - Josep Escribano-Alacid • Albert Martínez-Silvestre • \\ Isabel Verdaguer $\cdot$ Ralph Mac Nally
}

Received: 29 November 2018/ Accepted: 26 May 2019

(C) Springer Nature Switzerland AG 2019

\begin{abstract}
There are many pathways by which invasive species are introduced and become established, with the exotic pet trade becoming an increasingly important route. The abandonment of pets is a growing problem, which has been recognized widely and that has provoked some legislative responses. We developed an approach to deal with the abandonment issue that is more comprehensive than existing frameworks. We analyzed a substantial data set on exotic fish, crayfish and herptiles in northeastern Spain to illustrate the approach and its rationale. Spanish legislation mirroring the recently enforced European Strategy to control invasive species was introduced in 2011, and
\end{abstract}

Electronic supplementary material The online version of this article (https://doi.org/10.1007/s10530-019-02023-8) contains supplementary material, which is available to authorized users.
A. Maceda-Veiga ( $\square)$

Department of Evolutionary Biology, Ecology and Environmental Sciences \& Institute of Research in Biodiversity, Universitat de Barcelona (IRBio-UB), 08028 Barcelona, Spain

e-mail: albertomaceda@gmail.com

A. Maceda-Veiga

Department of Integrative Ecology, Estación Biológica de

Doñana (EBD-CSIC), 41092 Seville, Spain

J. Escribano-Alacid

Museu de Ciències Naturals de Barcelona,

08019 Barcelona, Spain we analyzed information from 2009 to 2018 to assess the effectiveness of the legislation. The 2011 legislation was intended to ban the sale of a prioritized list of invasive species in retailers, which aimed to reduce the release of exotic species into recipient ecosystems. We did not see any prohibited species for sale in retailers after 2011. However, 60,753 exotic animals from 4 classes, 10 orders, 47 families and 139 species were recorded in Barcelona and elsewhere in northeastern Spain, including 134 species other than the 5 prioritized invasive species. We found little evidence of a change in exotic pet releases into urban lakes after 2011. Invasive terrapins (Trachemys spp.) were captured in urban lakes and were the most prevalent taxon in a herptile rescue centre with increased numbers after 2011. We advocate a four-tier approach to deal

\author{
A. Martínez-Silvestre · I. Verdaguer \\ Catalonian Reptile and Amphibian Rescue Centre- \\ CRARC, 08783 Masquefa, Spain \\ R. Mac Nally \\ Institute for Applied Ecology, University of Canberra, \\ Bruce, ACT 2617, Australia \\ R. Mac Nally \\ Sunrise Ecological Research Institute (SERI-OG), \\ Ocean Grove 3226, Australia
}


more effectively with the pet-abandonment issue, which includes: (1) better understanding of uncertainties in the listing of potentially invasive species; (2) allowing would-be owners to seek accreditation (through training); (3) pit-tagging to ensure that animals can be associated with registered owners, including species now prohibited but that had been traded for decades; and (4) ensuring that adults of lowcost, small-size-at-purchase species are present at the point-of-sale to 'warn against' the consequences of impulsive purchases.

Keywords Keyword exotic pet trade $\cdot$ Introduction pathways · Legislation · Policy · Biosecurity ·

Propagule pressure

\section{Introduction}

Thousands of millions of animals are captive-reared or obtained from the wild each year for the exotic pet trade (Bush et al. 2014; OATA 2018). The trade has many critics because it can lead to overharvesting from natural habitats and the often-serious environmental and public health issues caused by the introduction, deliberate or accidental through escape, of invasive species around the world (Chomel et al. 2007; Bush et al. 2014; Hulme et al. 2017). Therefore, for the exotic pet trade to be sustainable in the long term, its drawbacks need to be reduced or eliminated, including the risk of introducing invasive species.

The European Union regulates the pet trade (e.g. Common Entry Veterinary Document, Regulation 338/1997) and recently has enforced a unified regulatory system to prevent the introduction of invasive species, including exotic pets (Regulation 1143/2014). This regulation includes a ban on the importation, trade, possession, breeding, transport, use, and release of the 'Invasive Alien Species of Union Concern' into the environment (Regulation 1143/2014). For this purpose, a prioritized list of species was generated from risk assessments, which is an evidence-based protocol that estimates the likelihood of a species' introduction, establishment, spread and impact given a species' ecological traits and prior invasion success (Luque et al. 2014; Genovesi et al. 2015). The success of unified regulations on the pet trade is exemplified by a ban on the trade of wild-caught birds in Europe
(Regulation 139/2013a, b; Reino et al. 2017). However, quantitative information on other taxa is needed because of the diversity of attitudes among pet owners and the different animal groups involved.

The trade in fish, crayfish and herptiles is among the most diverse in the global pet trade (Chucholl 2013; Auliya et al. 2016; OATA 2018), with > 1100 freshwater fish species traded in southwestern Europe alone (Maceda-Veiga et al. 2013). This trade involves some of the most at-risk animals on Earth, amphibians and freshwater fish (Living Planet Report 2018), but worryingly includes invasive species such as the redeared slider (Trachemys scripta elegans), the African clawed frog (Xenopus laevis) and the common carp (Cyprinus carpio) (DAISIE 2009). There are various reasons for animals becoming unwanted pets, but large adult body size is a primary one (Duggan et al. 2006; Stringham and Lockwood 2018). Nevertheless, legislation does not seem to have addressed effectively the risk of pets becoming unwanted. There is evidence of banned and permitted species generating similar problems for owners because of their large adult-size (e.g. T. s. elegans, T.s. scripta or Pseudemys nelsoni) (e.g. Fujisaki et al. 2010; Masin et al. 2014; Banha et al. 2017).

Feral pets occur in most cities around the world (e.g. King and Krakauer 1966; Pârâu et al. 2016), yet the factors influencing their release (i.e. initial invasion stages) are less well-studied than those promoting the establishment of exotic pet populations (Stringham and Lockwood 2018). Propagule pressure, which is the number and frequency of individuals released, is a major determinant of invasion success, alongside the tolerance of exotic species to climate in the recipient habitat (Lockwood et al. 2005; Masin et al. 2014). Governments often designate rescue centres, which collect feral pets, receive donations from pet owners and confiscations from responsible authorities (Fig. 1). Therefore, information on exotic-pet confiscations and on-ground inspections of retailers and urban areas for the presence of dumped pets might provide a basis for an improved regulation of the exotic pet trade.

Our goal was to examine the impact that the strict regulation of the trade, holding, and transport of exotic invasive species that was enforced in Spain in 2011 (RD1628/2011; RD630/2013) has had on the sale of prohibited species in retailers and on the number of disposed exotic pets in northeastern Spain from 2009 


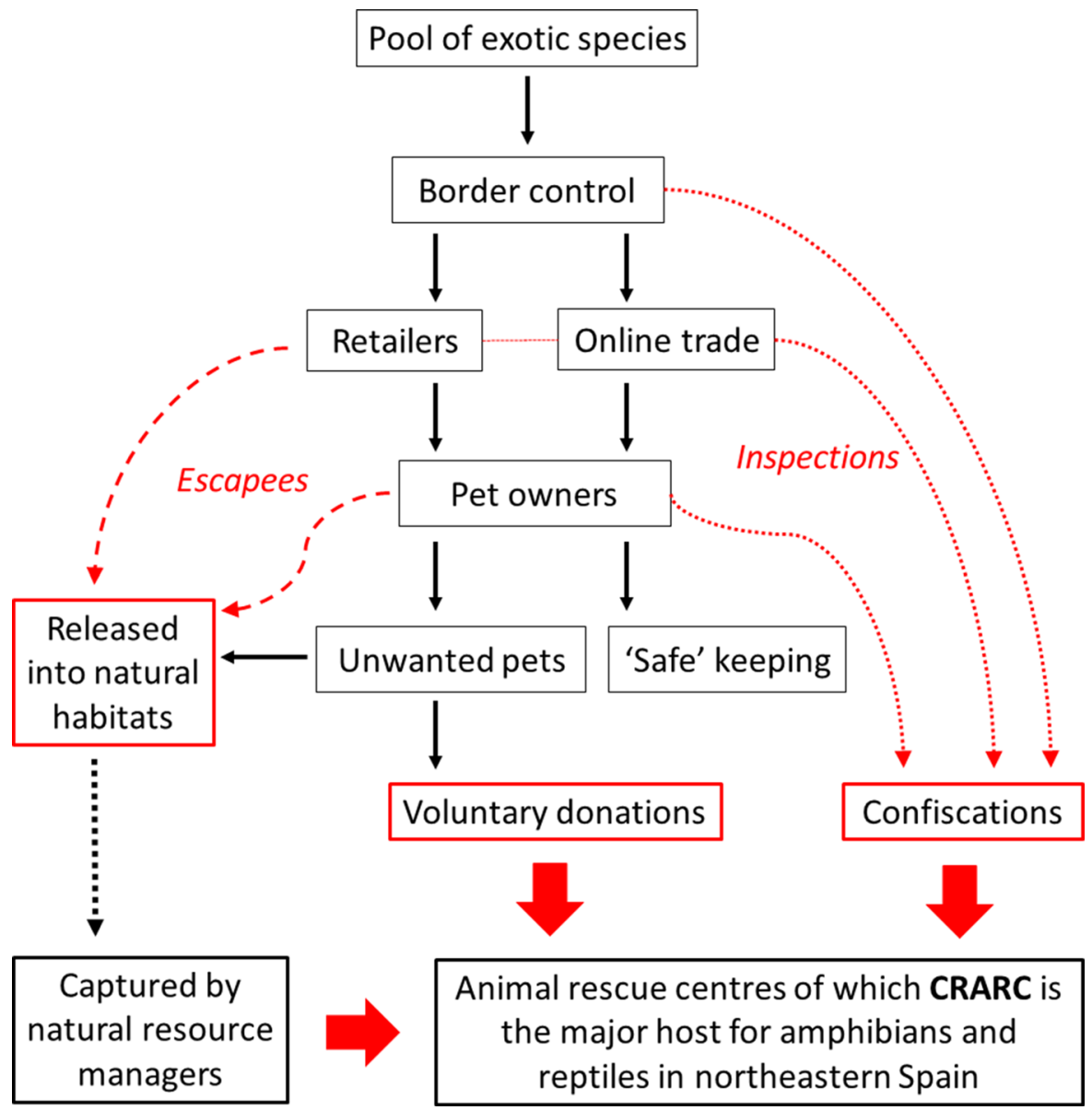

Fig. 1 Sources of amphibians and reptiles that arrive in the animal rescue centre CRARC from the international exotic pet trade: voluntary donations from pet owners are all unwanted pets; captures in natural habitats are unwanted pets or escapees

to 2018. We focused on this area because it accounts for the first records of several aquatic invasions in Iberia (e.g. Misgurnus anguillicaudatus, Pseudorasbora parva, Caiola and Sostoa 2002; Franch et al. 2008). We expected that prohibited invasive pets would not be for sale in retailers after the implementation of the 2011 legislation. Moreover, we expected that the number of exotic pets released would decline over the study period. Last, we use the provisions of existing regulation to construct a framework for dealing more effectively with the multiple aspects involved in the trade of exotic pets, including the release of potentially invasive species. including more species with potential to establish in nature than voluntary donations from pet owners; and confiscations include all types of illegal trade, including prohibited invasive species

\section{Methods}

Data sources

We used three data-sets as indicators of the number of unwanted exotic pets in northeastern Spain: records from an animal rescue centre from 2009 to 2018, animals recovered from urban lakes in Barcelona from 2011 to 2018, and inspections of 13 pet retailers in Barcelona between 2011 and 2018 for the presence of prohibited invasive species under the Spanish Acts RD1628/2011 and RD630/2013.

The Catalonian Reptile and Amphibian Rescue Centre (CRARC) is the reference centre in the region for wild-collected exotic amphibians and reptiles, voluntary delivers by pet owners or authorities' 
confiscations (Fig. 1). The Galanthus association provided data on the number and species released into 11 urban lakes in Barcelona, which included terrapins that are not delivered to CRARC but to other animal rescue centres, and fish, a faunal group that CRARC did not collect. With $>1.6$ million citizens, Barcelona is the second most populous city in Spain and the sixth in the European Union if the metropolitan area of Barcelona ( $>5$ million citizens) is considered (IDESCAT 2019). The eleven studied lakes were in districts representative of the variety of social classes in Barcelona and had an average area $( \pm$ SD) of $3873 \pm 5159 \mathrm{~m}^{2} \quad$ (minimum-maximum range: $400-14,300 \mathrm{~m}^{2}$ ). These are the only lakes in the city that are completely emptied every year, from which all stranded individuals were identified and counted. These data are good proxy for propagule pressure from which the risk of establishment might be better estimated than by using CRARC data alone. Data from Galanthus and CRARC were complemented by monthly surreptitious inspections of 13 pet retailers in Barcelona. The retailers inspected were the $90 \%$ of exotic pet retailers in Barcelona city and ranged from small, family businesses focused on specific type of animals (e.g. aquatic exotic pets) to large companies selling terrestrial animals (e.g. dogs, birds, rabbits) alongside exotic aquatic pets. All analyses were conducted in R (R Core Team 2013).

\section{Data analyses}

The response variables were the number and species richness of prohibited invasive species recorded in retailers, CRARC and urban lakes. These responses were used to assess the effectiveness of Acts RD1628/ 2011 and RD630/2013 on the trade, holding, and transport of exotic invasive species in northeastern Spain, alongside the overall trend in the number of unwanted or illegal exotic pets. We used the Chao1 species-richness estimator to determine whether more species than those collected have the potential to be released into urban lakes or to arrive in CRARC because all inventories of exotic species are likely to be incomplete. Non-parametric species estimators, such as Chaol, estimate the probable number of species from species-abundance curves by using the number of species recorded just one time (singletons) or twice (doubletons) in a data set (Colwell and Coddington 1994).
Visual inspection of distributions of response variable suggested that the most appropriate distributions for modelling were log-normal for abundance and Poisson for richness. Changes in the observed abundance and richness of exotic pets through time were examined separately for each animal group using generalized linear models for urban lake data and generalized linear mixed models for CRARC data. Random effects were used for lake ID to account for within-lake variation in exotic pet releases into urban lakes. For each response variable, we fitted three models corresponding to specific hypotheses: (1) null model, just an intercept $(\alpha)$ or intercept $(\alpha)+$ random effect for lake ID, asserting that there were no differences among years; (2) null model + year, suggesting a linear trend with time; and (3) null model + year + year $^{2}$, corresponding to a non-linear (quadratic) trend through time. We used the Akaike Information Criterion corrected for small sample size (AICc) to identify the most plausible model (i.e. the one with the lowest AICc value). The fit of the best model was determined, such as: (null deviance residual deviance)/null deviance, and was the criterion used to discern between two models considered equally plausible (deviation of $<2$ units of AICc). Significance of the factor 'year' was assessed using likelihood-ratio tests at $P \leq 0.05$ within the function Anova in the package car (Fox and Weisberg 2011). Models were validated by using diagnostic plots of model residuals.

If education campaigns and legislation have mitigated the issue of unwanted exotic pets, including the possession of illegal invasive species, then there should be a significant overall reduction in the number and richness of exotic pets in data from CRARC and the urban lakes over the duration of the study. For CRARC, such a decrease should be particularly apparent if one compared the number and richness of exotic pets that arrived in the years before (2009-2011) and after (2012-2018) the enforcement of the Spanish Acts RD1628/2011 and RD630/2013. The number of voluntary donations compared to confiscations and captures in the wild is a measure of the degree of public awareness on the issue of unwanted exotic pets, including listed invasive species. 


\section{Results}

There were 60,753 exotic animals from four classes, ten orders, 47 families and 139 species in the data from CRARC (2009-2018) and the urban lakes in Barcelona (2011-2018) combined. The class Reptilia had the highest taxonomic richness (29 families and 109 species), and Malacostraca had the lowest, with only the redswamp crayfish Procambarus clarkii being recorded (Appendix S1). The number of species for all animal types was between 1.12 and 5.57 lower than those expected from the Chao1 richness estimator, with crocodiles having the lowest and testudines the highest estimated species richness (Table 1).

The most frequent exotic pets in CRARC and urban lakes

Terrapins accounted for most of the 14,965 CRARC records, with T. s. scripta being $46 \%$ of the 13,689 testudines (terrapins and turtles) recorded (Table 2). Newts were the second most common taxon in CRARC but much less abundant, with $68 \%$ of the 497 entries being Ommatotriton ophriticus $\times$ vittatus (Table 2). Of the 371 lizards at CRARC, 38\% were Iguana iguana and $27 \%$ Pogona vitticeps (Table 2). A total of 345 snakes was recorded, Python regius (32\%) and Pantherophis guttata (24\%) were the dominant

Table 1 Descriptive statistics for the richness and abundance of exotic aquatic pets recorded annually in the 11 urban lakes in Barcelona and in the rescue centre CRARC, which receives animals from all northeastern Spain. The only testudines species (Table 2). Only 6 crocodiles and 57 frogs arrived in CRARC, with Caiman crocodilus (50\%) and Epipedobates tricolor (32\%) accounting for most of the crocodile and frog records (Table 2).

Fish dominated captures in urban lakes $(44,475)$, with the invasive G. holbrooki (63\%) and goldfish Carassius auratus (35\%) being the most common species (Table 2). The invasive $P$. clarkii also was abundant, with 1004 of the 45,788 animals captured in total (Table 2). Terrapins were much less abundant in the urban lakes (309), with the dominant species being the invasive Trachemys scripta scripta (41\%; Table 2).

Patterns in unwanted and illegal exotic pets through time

The 13 retailers inspected from 2011 to 2018 did not have prohibited invasive pets apart from the eastern mosquitofish Gambusia holbrooki, which was a species that does not have ornamental interest, and was found mixed in goldfish stocks in 3 of the 84 visits to one retailer. However, seven listed invasive species were captured in urban lakes in Barcelona from 2011 to 2018, including fish, crayfish and terrapins (Fig. 2, Table 1). Five listed invasive species were delivered to CRARC after 2011, including the terrapins Chrysemys picta and T. s. troostii, none of which were

recorded in urban lakes were terrapins but there were terrapins and turtles in CRARC data. Procambarus clarkii was the only crayfish species

\begin{tabular}{|c|c|c|c|c|c|c|c|c|c|}
\hline & \multicolumn{3}{|c|}{ Richness } & \multicolumn{3}{|c|}{ Estimated richness (Chao 1) } & \multicolumn{3}{|c|}{ Abundance } \\
\hline & Mean & 95\% C.L. & Min-Max & Mean & 95\% C.L. & Min-Max & Mean & 95\% C.L. & Min-Max \\
\hline \multicolumn{10}{|l|}{ Urban lakes } \\
\hline Procambarus clarkii & - & - & - & - & - & - & 201 & $24.99-377.01$ & $0-600$ \\
\hline Fish & 1.32 & $1.19-1.44$ & $0-4$ & 7.27 & $6.45-8.09$ & $1.65-11.00$ & 1202 & $515.54-1888.46$ & $0-12,000$ \\
\hline Testudines & 1.68 & $0.14-3.22$ & $0-7$ & 9.36 & $7.87-10.85$ & $2.45-12.12$ & 8.35 & $3.29-13.40$ & $0-130$ \\
\hline \multicolumn{10}{|l|}{ CRARC } \\
\hline Frogs & 7 & $4.5-9.6$ & $1.3-11$ & 11.6 & $8.4-14.8$ & $1.6-19.1$ & 5.2 & $4.6-5.7$ & $1-18$ \\
\hline Newts & 5 & $2.1-8.2$ & $1.9-8$ & 5.6 & $4.6-6.6$ & $1.9-9$ & 62 & $61.4-62.8$ & $1-337$ \\
\hline Lizards & 20.6 & $17.7-23.4$ & $8-30$ & 25 & $22-27$ & $11-35$ & 12.4 & $12.1-13$ & $1-140$ \\
\hline Crocodiles & 2.2 & $1.29-3.1$ & $0.8-3.0$ & 2.9 & $2.3-3.5$ & $0.8-3.9$ & 2 & $0.8-3.1$ & $1-3$ \\
\hline Snakes & 18 & $14.3-22.7$ & $7.5-27$ & 23.7 & $20.6-26.8$ & $8.6-35.2$ & 12.8 & $12.4-13.2$ & $1-109$ \\
\hline Testudines & 44.8 & $38.5-51.1$ & $27-55$ & 63 & $54.8-71.3$ & $32.4-105$ & 240.2 & 239.9-240.4 & $0-6241$ \\
\hline
\end{tabular}


Table 2 List of the three most abundant species for each animal type (if present or if the abundance was $>0.6 \%$ ) captured in the urban lakes in Barcelona or arrived in the animal rescue centre CRARC. CRARC data included two groups of testudines (terrapins and turtles), but only terrapins were collected in urban lakes

\begin{tabular}{|c|c|c|c|}
\hline Urban lakes & $\%$ & & $\%$ \\
\hline Crayfish & & Testudines & \\
\hline \multirow[t]{2}{*}{ Procambarus clarkii } & 100.0 & Trachemys scripta scripta & 41.4 \\
\hline & & Pseudemys nelsoni & 24.9 \\
\hline Fish & & Pseudemys concinna & 16.5 \\
\hline Gambusia holbrooki & 63.3 & & \\
\hline Carassius auratus & 35.2 & & \\
\hline Poecilia reticulate & 0.9 & & \\
\hline CRARC & $\%$ & & $\%$ \\
\hline Frogs & & Newts & \\
\hline Epipedobates tricolor & 31.6 & Ommatotriton hybrid ${ }^{\mathrm{a}}$ & 67.8 \\
\hline Mantella crocea & 21.1 & Triturus hybrid ${ }^{\mathrm{b}}$ & 11.9 \\
\hline Bombina orientalis & 15.8 & Ommatotriton vitattus & 5.0 \\
\hline Lizards & & Crocodiles & \\
\hline Iguana iguana & 37.7 & Caiman crocodilus & 50.0 \\
\hline Pogona vitticeps & 26.9 & Crocodylus niloticus & 33.0 \\
\hline Eublepharis macularius & 8.9 & Paleosuchus palpebrosus & 17.0 \\
\hline Testudines & & Snakes & \\
\hline Trachemys scripta scripta & 45.6 & Python regius & 31.6 \\
\hline Trachemys scripta elegans & 21.3 & Pantherophis guttata & 23.5 \\
\hline Testudo graeca & 7.9 & Lampropeltis getula & 10.7 \\
\hline
\end{tabular}

${ }^{\mathrm{a} O m m a t o t r i t o n}$ ophryacus $\times$ vittatus

${ }^{\mathrm{b}}$ Triturus cristatus $\times$ anatolicus

found in urban lakes (Fig. 2). Most of the animals that arrived in CRARC (90\%) were voluntary donations by pet owners, with the remainder being the $8 \%$ wild captures and $2 \%$ confiscations by authorities (customs, police). The exceptions were newts, which were mostly confiscated $(25 \%)$ or captured in the wild (74\%), all having very local distributions, such as $O$. ophriticus $\times$ vittatus that was captured in just one locality.

The null models were the best models to explain variation in the number and richness of exotic pets from the four animal groups in urban lakes (Table 3). The factor 'year' had neither a significant linear nor quadratic relationship with the richness of most animal groups in CRARC data from all three sources combined (voluntary donations, captures in the wild or confiscations, Table 3). The exceptions were the richness of frogs and newts, which showed, respectively, a significant positive and negative linear trend with year (Table 3). Variation in the abundance of testudines, frogs and listed invasive species that arrived in CRARC was best explained by a quadratic response with year (Table 3). Change in the abundance of snakes, newts and lizards instead was better explained by a negative linear trend with year (Table 3).

When comparisons within CRARC data were restricted to two periods to specifically assess the effect of the legislation on the different animal sources (pre-2011, post-2011), there was a significant increase in the number of testudines and listed invasive animals that arrived in CRARC voluntary delivered by pet owners after 2011 (Table 4, Fig. 3). Conversely, the number of voluntarily delivered frogs, lizards and snakes was higher in pre- than in post-legislation periods (Table 4, Fig. 3). The same pattern was seen for the number of confiscated frogs. Confiscations and voluntary donations of exotic newts only occurred 
Fig. 2 Changes in the abundance of the most common fish (top panel) and terrapin species (bottom panel) collected in the urban lakes in Barcelona, including $G$. holbrooki, $C$. carpio, T. s. elegans and T. s. scripta, all of which are listed as invasive exotic species in the Spanish Act RD1628/2011

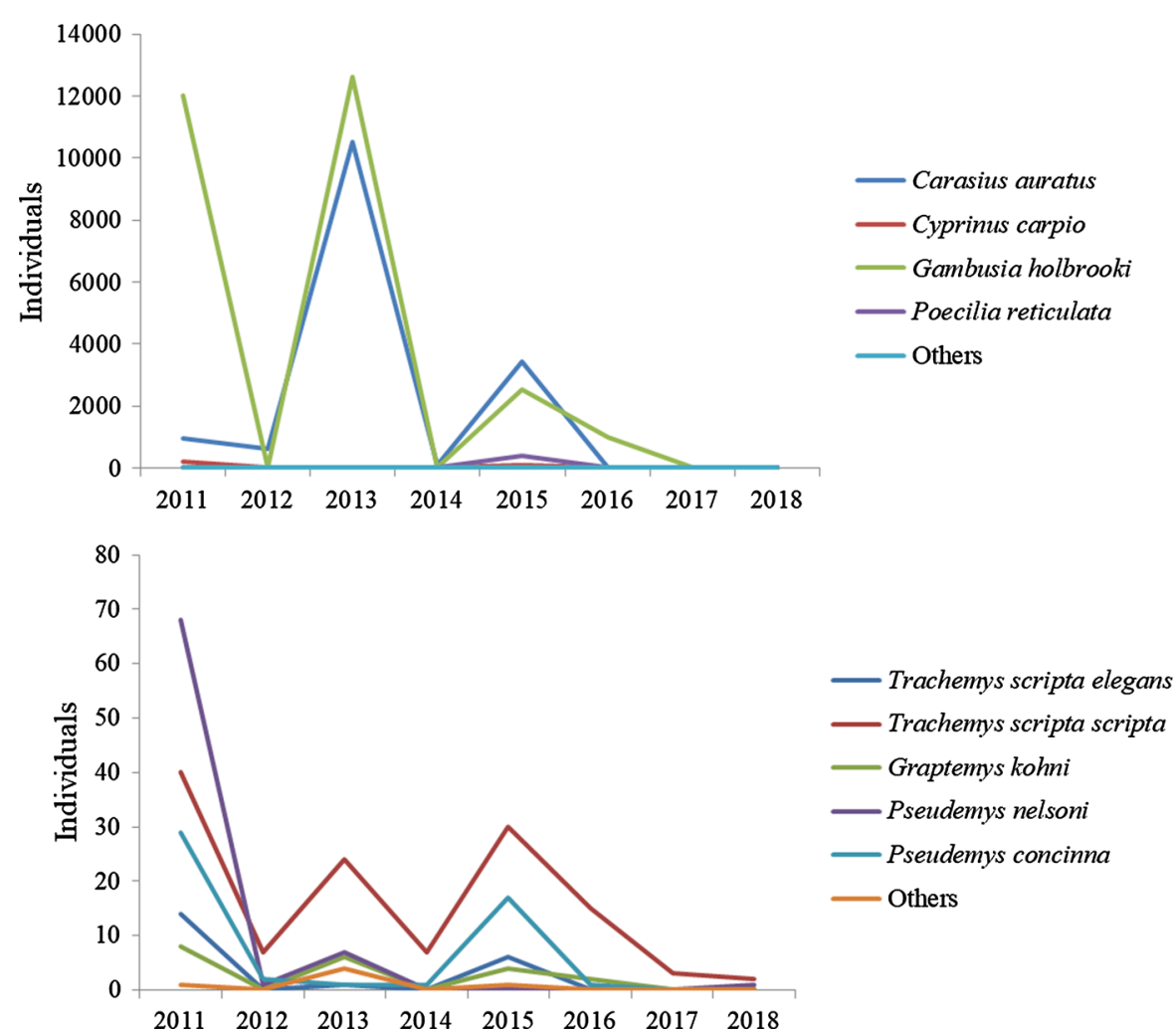

after 2011, and confiscations of listed invasive species and captures of exotic newts in the wild only occurred before 2011. No pattern was seen after 2011 for any other animal groups (Table 4).

\section{Discussion}

Did the new legislation curb the sale and release of listed invasive species?

Our work suggests that legislation, such as the Spanish Acts (RD1628/2011; RD630/2013), has been effective at curbing the sale of listed invasive species by retailers (Miller 2011; but see Fowler et al. 2007; García-Díaz et al. 2017). However, the release of prioritized listed species into urban lakes continued virtually unabated, possibly because education campaigns were not conducted at the same time (e.g. OATA 2015). The most frequently recorded species in CRARC were similar to those collected from urban lakes notwithstanding that CRARC also received herptiles from confiscations (e.g. Mantella crocea, Crotalus sp.). The number of unwanted terrapins is consistent with the herptile market being dominated by young terrapins, with an annual export of up to 4 million animals from the USA alone (Stringham and Lockwood 2018). Pet owners probably were not responsible for many of the individuals of fish and crayfish recovered. Carassius auratus and G. holbrooki were the most common exotic species, and these species mature in $<1$ year and breed easily in urban lakes (AMV \& JEA pers. obs.). Gambusia holbrooki is not of ornamental interest, so that the ongoing releases may be due to decades of official recommendation for the use of this species for mosquito control (DAISIE 2009). Procambarus clarkii and the largemouth bass Micropterus salmoides probably were released by anglers because these species are not for sale in Barcelona aquarium retailers (JEA \& AMV pers. obs.). However, P. clarkii is a common German aquatic exotic pet and breeds easily in captivity (Chucholl 2013). 
Table 3 Comparison of Akaike information criterion (AIC) values showing the likelihood that variation in the total abundance and richness of the animal groups that entered urban lakes and the animal rescue centre CRARC had linear or quadratic relationships with year. Urban lakes were surveyed from 2011 to 2018 and CRARC data ranged from 2009 to
2018. Null model included only the intercept for CRARC and the intercept plus random effects for lakes in urban-lake models. We provide measures of fit (pseudo- $R^{2}$ ) and equations for the best models (in bold; i.e. the lowest AIC value) that included 'year' as significant predictor at $P \leq 0.05$ using the function Anova (Fox and Weisberg, 2011)

\begin{tabular}{|c|c|c|c|c|c|}
\hline & Null & Linear & Quadratic & Model fit & Equation of the best model \\
\hline \multicolumn{6}{|l|}{ Urban lakes } \\
\hline Abundance of fish & 144.4 & 150.2 & 148.0 & - & - \\
\hline Richness of fish species & 83.7 & 86.1 & 87.0 & - & - \\
\hline Abundance of testudines & 89.9 & 95 & 92.7 & - & - \\
\hline Richness of testudine species & 96.8 & 97.8 & 99.5 & - & - \\
\hline Abundance of prohibited spp. & 145.9 & 151.7 & 149.8 & - & - \\
\hline Richness of prohibited spp. & 72.7 & 85.4 & 76.3 & - & - \\
\hline \multicolumn{6}{|l|}{ CRARC } \\
\hline Abundance of frogs & 111.4 & 90.1 & 83.1 & 0.39 & $\mathrm{y}=1.25-3.51$ year -1.7 year $^{2}$ \\
\hline Richness of frog species & 36.3 & 32.9 & 34.7 & 0.40 & $\mathrm{y}=4.05-0.2 \cdot$ year \\
\hline Abundance of newts & 1511.5 & 1477.6 & 1478.3 & 0.02 & $\mathrm{y}=194.5-0.09$ year \\
\hline Richness of newt species & 38.9 & 30.4 & 31.0 & 0.38 & $y=-736.6+0.37$ year \\
\hline Abundance of lizards & 116.6 & 107.6 & 108.5 & 0.18 & $\mathrm{y}=124.4-0.06$ year \\
\hline Richness of lizard species & 45.5 & 47.2 & 48.4 & - & - \\
\hline Abundance of snakes & 101.8 & 97.2 & 98.8 & 0.14 & $\mathrm{y}=100.5-0.05$ year \\
\hline Richness of snake species & 48.5 & 49.8 & 50.8 & - & - \\
\hline Abundance of crocodiles & 20.1 & 21.8 & 22.3 & - & - \\
\hline Richness of crocodile species & 20.1 & 21.8 & 22.1 & - & - \\
\hline Abundance of testudines & 400.8 & 240.8 & 199.2 & 0.67 & $\mathrm{y}=7.21+0.36$ year -0.16 year $^{2}$ \\
\hline Richness of testudine species & 58.1 & 59.0 & 60.6 & - & - \\
\hline Abundance of prohibited spp. & 375.1 & 367 & 229.5 & 0.52 & $\mathrm{y}=6.88-0.11$ year -0.38 year $^{2}$ \\
\hline Richness of prohibited spp. & 37.7 & 38.4 & 40.4 & - & - \\
\hline
\end{tabular}

spp. species

The issue of unwanted exotic pets goes beyond invasion risk

We found 134 exotic species other than the five prohibited species under the 2011 legislation, suggesting that past efforts to manage invasions have not been enough (see also Seebens et al. 2017). We believe that a primary reason probably is that legislation is reactive (i.e. prohibits species already known to be invasive) rather than proactive (i.e. reducing the likelihood of a species being released) (see also Miller 2011; Hulme 2015). Proscribing a pet species requires detailed quantitative data (Shine et al. 2010; Essl et al. 2011; Genovesi et al. 2015) but the invasion risk may be uncertain if the prior invasion history and tolerance of species to minimum water temperature are poorly known (e.g. Masin et al. 2014; Howeth et al. 2016).

Another problem for assessing the risk of establishment is that minimum temperature can differ substantially within a country, such as Spain, let alone within Europe if the aim is a unified European strategy for the management of invasive species as proposed under the EU Regulation 1143/2014. Such a poor knowledge of temperature tolerances can be addressed by allowing the sale of just those species with a wellestablished low invasion risk using regional risk assessments on imported official lists of species (e.g. Clavero 2011; Almeida et al. 2013). However, controlling invasions through permitted-species lists (i.e. White List, see Perrings et al. 2005; Miller 2011) probably do little to stem the release of many exotic 
Table 4 Statistics for the comparison of the abundance and richness of the taxonomic groups that arrived in CRARC from voluntary delivers by pet owners, captures in nature and confiscations made by authorities the years (2009-2011) and after (2012-2018) the enforcement of the legislation on invasive exotic species (RD1628/ 2011). The effects of legislation on the prohibited invasive species is specifically shown

\begin{tabular}{|c|c|c|c|c|}
\hline & Abundance & & Richness & \\
\hline \multicolumn{5}{|l|}{ Frogs } \\
\hline Voluntary deliveries & $\chi^{2}=9.9$ & $P<0.001$ & $\chi^{2}=3.2$ & n.s. \\
\hline Captures in nature & $\chi^{2}=2.3$ & n.s. & $\chi^{2}=0.02$ & n.s. \\
\hline Confiscations & $\chi^{2}=10.4$ & $P<0.001$ & $\chi^{2}=0.7$ & n.s. \\
\hline \multicolumn{5}{|l|}{ Newts } \\
\hline Voluntary deliveries & $\chi^{2}=2.3$ & n.s. & $\chi^{2}=2.9$ & n.s. \\
\hline Captures in nature & $\chi^{2}=819.9$ & $P<0.001$ & $\chi^{2}=0.2$ & n.s. \\
\hline Confiscations & $\chi^{2}=89.2$ & $P<0.001$ & $\chi^{2}=4.3$ & $P=0.03$ \\
\hline \multicolumn{5}{|l|}{ Lizards } \\
\hline Voluntary deliveries & $\chi^{2}=20.4$ & $P<0.01$ & $\chi^{2}=1.2$ & n.s. \\
\hline Captures in nature & $\chi^{2}=0.7$ & n.s. & $\chi^{2}=0.1$ & n.s. \\
\hline Confiscations & $\chi^{2}=1.9$ & n.s. & $\chi^{2}=1.3$ & n.s. \\
\hline \multicolumn{5}{|l|}{ Snakes } \\
\hline Voluntary deliveries & $\chi^{2}=8.9$ & $P<0.001$ & $\chi^{2}=0.9$ & n.s. \\
\hline Captures in nature & $\chi^{2}=3.3$ & n.s. & $\chi^{2}=1.6$ & n.s. \\
\hline Confiscations & $\chi^{2}=0.01$ & n.s. & $\chi^{2}=0.5$ & n.s. \\
\hline \multicolumn{5}{|l|}{ Crocodiles } \\
\hline Voluntary deliveries & $\chi^{2}=0.02$ & n.s. & $\chi^{2}=0.02$ & n.s. \\
\hline Captures in nature & $\chi^{2}=2.4$ & n.s. & $\chi^{2}=2.4$ & n.s. \\
\hline Confiscations & $\chi^{2}=1.4$ & n.s. & $\chi^{2}=1.4$ & n.s. \\
\hline \multicolumn{5}{|l|}{ Testudines } \\
\hline Voluntary deliveries & $\chi^{2}=244.4$ & $P<0.001$ & $\chi^{2}=0.65$ & n.s. \\
\hline Captures in nature & $\chi^{2}=0.12$ & n.s. & $\chi^{2}=0.31$ & n.s. \\
\hline Confiscations & $\chi^{2}=2.71$ & n.s. & $\chi^{2}=0.02$ & n.s. \\
\hline \multicolumn{5}{|l|}{ Prohibited spp. } \\
\hline Voluntary deliveries & $\chi^{2}=150.7$ & $P<0.001$ & $\chi^{2}=1.5$ & n.s. \\
\hline Captures in nature & $\chi^{2}=0.96$ & n.s. & $\chi^{2}=1.1$ & n.s. \\
\hline Confiscations & $\chi^{2}=9.63$ & $P<0.001$ & $\chi^{2}=7.2$ & $P=0.01$ \\
\hline
\end{tabular}

pets, which may be of ecological concern. Exotic pets, even if they fail to establish, may introduce pathogens into recipient water bodies (e.g. ranavirus, Salmonella, Johnson and Speare 2003; Schloegel et al. 2009; Lafuente et al. 2013; Demkowska-Kutrzepa et al. 2018).

The assessment of invasion risk of exotic pets is complicated further by increasing species diversity in the trade, with similar trends in many countries. The most frequently seen species of terrapins in Barcelona's urban lakes and CRARC were similar to those elsewhere in Europe and in the USA (Masin et al. 2014; Stringham and Lockwood 2018). The number of freshwater fish species in Spanish retailers (294 species, Maceda-Veiga et al. 2013) is similar to the number of species in retailers from the USA and
Canada markets (e.g. 252 species, Chapman et al. 1997; Rixon et al. 2005). However, there are $>1200$ aquarium fish species for sale by wholesalers and by e-commerce (Padilla and Williams 2004; MacedaVeiga et al. 2013; Raghavan et al. 2013).

Time to be more proactive to stem exotic pet releases: leaking doors and irresponsible buying

Pet abandonment is a criminal offence in an increasing number of developed countries (e.g. USA; Georgia Animal Protection Act of 1986), but perpetrators usually escape detection and hence prosecution. Consequently, pet abandonment is mostly addressed by owner education (e.g. the Habitattitude ${ }^{\mathrm{TM}}$ campaign, http://www.habitattitude.net/) and by the provision of 

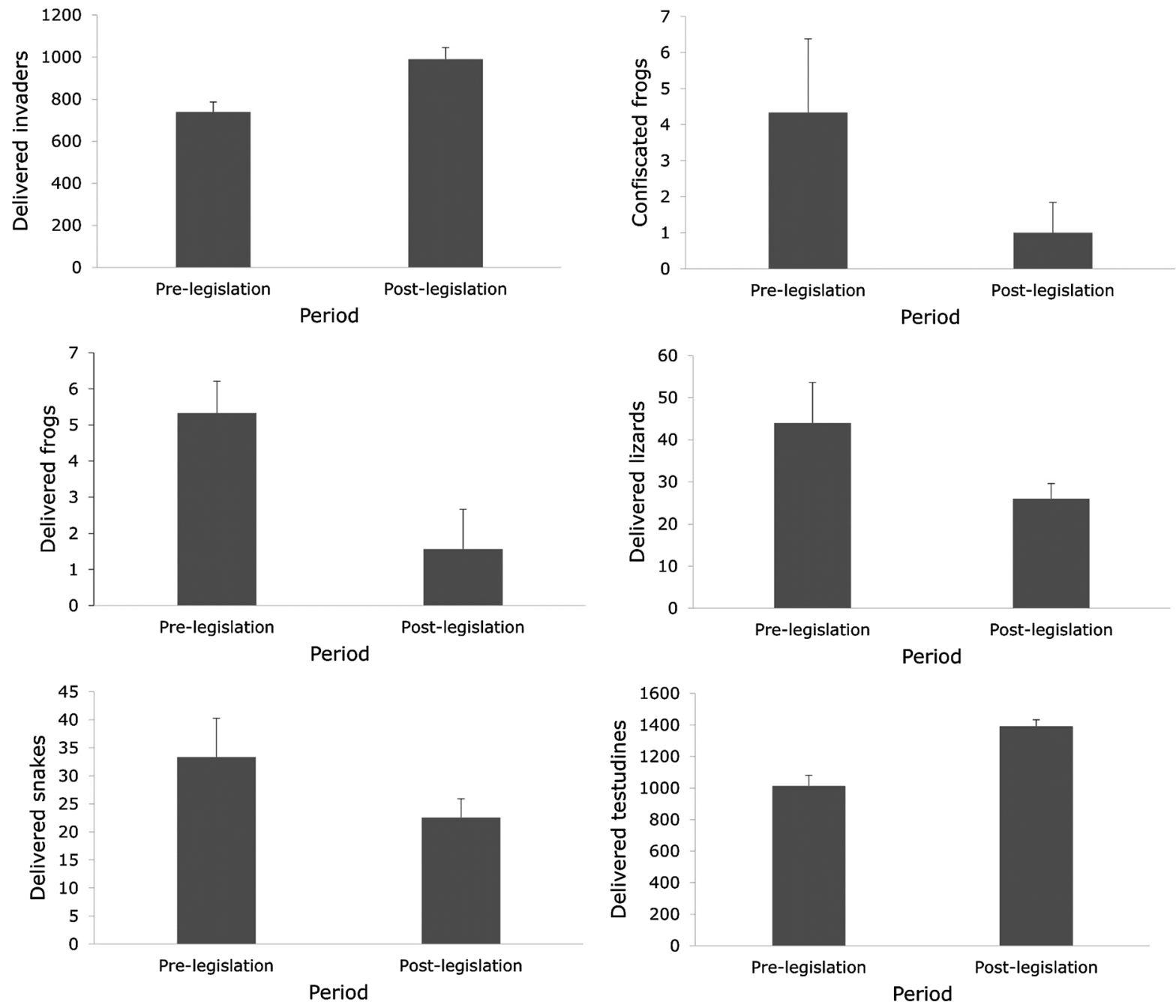

Fig. 3 Changes in the mean abundance ( \pm standard error) of exotic species from the taxonomic groups and sources (voluntary deliveries, captured in nature and confiscations) showing significant differences (see Table 4 and main text)

shelters, where pet owners can leave unwanted animals (Rowan 1992). However, there is the pressing need to have more specific policy to manage pet abandonment. Regulation is better than outright bans because the latter may increase the black-market value of banned species (Conrad 2012), and our study shows that bans have questionable effectiveness in preventing the release of already widely distributed invasive species. No regulation will fully stop animal abandonment, but if the main legal action to curb exotic pet releases is a ban on known invasive species, we envisage more pet abandonments and invasions. Therefore, knowledge of the characteristics of released pets help to put forward

before (2009-2011) and after (2012-2018) enforcement of the first legislation on invasive exotic species (RD1628/2011). The effect of legislation on the numbers of prohibited exotic is specifically shown

more specific policy to manage pet abandonment and would be better deal with a potentially increased invasion risk of tropical pets associated with global warming (Fig. 4).

A first regulatory proposal is to improve biosecurity measures in aquatic facilities because this has been a major introduction pathway for exotic fish and invertebrates in many regions (Courtenay and Stauffer 1990; Maceda-Veiga et al., 2016; Weyl et al. 2016). Of the 28 fish species established into Spanish waters, most can be traced to administrative stocking or angling (Maceda-Veiga 2013). The aquarium trade is responsible for the successful establishment of four 
(A)

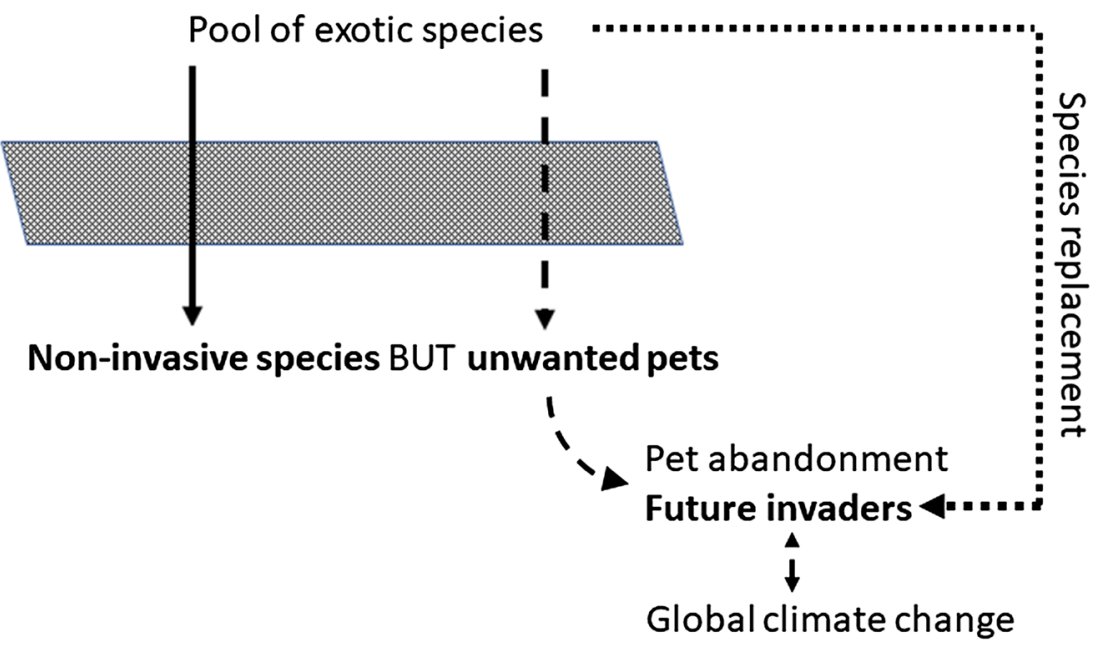

(B)

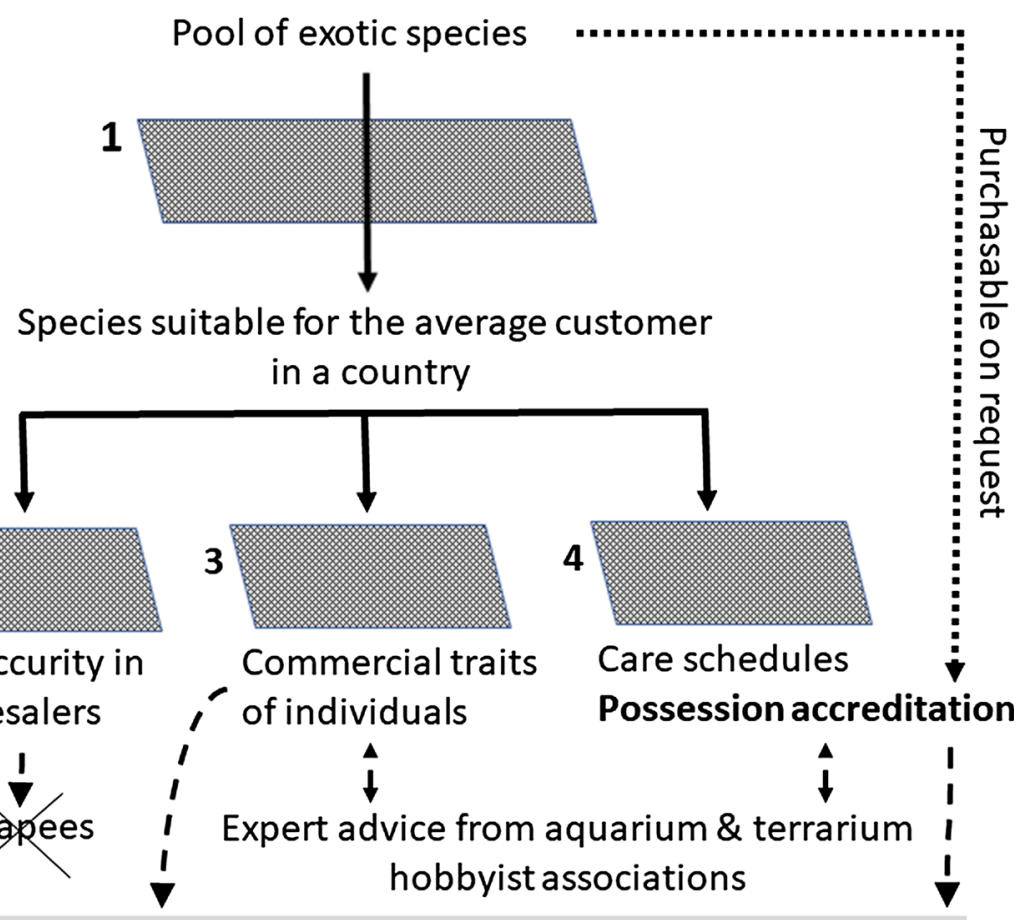

Trace purchased exotic pets \& promote their responsible possession, reducing exotic pet issues including invasions

Fig. 4 Current regulation on the management of unwanted exotic pets is focused on invasion risk (A) but has many uncertainties associated with climate change and trade diversity and says little about pet abandonment. Our more general fourtier approach (B) address pet abandonment directly by regulating the species that can be readily available for sale in retailers using the characteristics of the typical living space of an average customer (1), and increasing the size at retailers of individuals that are cheap and attain large adult sizes to avoid impulse purchases (3). More effective animal-care schedules for retailers developed in collaboration with expert hobbyists and veterinarians, pit tagging exotic herptiles before leaving the retailer, and the need to show an accreditation before purchasing an exotic pet will further promote responsible tenancy and animal welfare (4). For aquarium fish, aquaculture have been the main pathway of introduction into natural waters, so more effective biosecurity measures (nets, effluent disinfection) should be mandatory (2) 
species, including $P$. parva and $M$. anguillicaudatus (e.g. Caiola and Sostoa 2002; Franch et al. 2008), even though there are several reported failed establishments (e.g. Serrasalmus nattereri, Barbonymus schwanenfeldii; Gante et al. 2008; Maceda-Veiga 2013). Improving biosecurity measures also applies to research facilities, where aquarium-like fish are often used in experimental assays and may have accidentally led to the introduction of Fundulus heteroclitus (Gisbert and López 2007). We suggest that the use of net-traps and compulsory disinfection of water effluents from aquatic facilities would help to prevent the release of noxious organisms into natural waters. However, these measures probably do little to deal with aquatic herptiles, whose introduction is mostly due to pet-owner releases (Masin et al. 2014). Invasion risk may be reduced if only the sale of captive-bred animals is allowed, as for birds (EU Regulation 139/2013; Reino et al. 2017). Nevertheless, this rationale may not apply in other taxa because Trachemys terrapins are all captive-bred but have a high invasion success (e.g. Masin et al. 2014; Banha et al. 2017).

A second regulatory proposal is to filter the species readily available for sale (i.e. species in retailer cages) as function of adult size and the type of human living quarters of owners in each country. Hard-to-obtain species might be purchased on request if an accreditation scheme were to demonstrate that an owner has the expertise and ability to house larger pets, including the common caiman (C. crocodilus) and the green iguana (I. iguana) (Table 2). The trade in freshwater aquarium fish consists of many small adult-body-sized species $(<10 \mathrm{~cm}$, see Duggan et al. 2006; MacedaVeiga et al. 2016), which are suitable for the most frequently sold tank volume by Spanish retailers ( $\leq 60 \mathrm{~L}$, AMV pers. obs.). However, these tanks are inadequate for the large adult-body-size fish species captured in urban lakes, such as the common pleco (Hypostomus plecostomus) and the striped catfish (Pangasianodon hypophthalmus) (Appendix S1, Axelrod 2007). This rationale applies to terrapins because a $5-\mathrm{cm}$ terrapin of frequently collected species, such as G. kohni, P. floridiana, can grow fivefold in 12 months (JEA pers. obs.). Although small containers can be used for transport, they often are misused for long-term pet housing, with $>95 \%$ of terrapins donated to CRARC being kept in such undersized containers (Appendix S2).
A third measure is to prevent the direct sale of lowpriced, small-sized $(5 \mathrm{~cm})$ juveniles of species that grow to large body sizes, but to allow the sale of larger individuals. The small size of large adult body size (c. $30 \mathrm{~cm}$ ) terrapins and a relative low price (c. $15 €)$ may induce impulsive purchases (Stringham and Lockwood 2018). Compulsory tagging of pets prior to purchase will allow tracing of delinquent owners because even small-sized animals can be pit-tagged (e.g. newts, Perret and Joly 2002). Even though adult small-sized animals can become invaders (e.g. $P$. parva, DAISIE 2009), this generally is infrequent for the typical unwanted pet (Appendix S1). The engagement of all stakeholders in regulation is essential for a successful scheme and the collaboration of the oftenoverlooked expertise of aquarium and terrarium hobbyists would be beneficial to manage unwanted exotic pets and to conduct education campaigns (Maceda-Veiga et al. 2016; Pasmans et al. 2017).

A fourth regulatory avenue is to promote effective care schedules for exotic pets, including bans on the sale of inadequate containers (e.g. Appendix S2). CRARC necropsies revealed that $90 \%$ terrapins were in poor condition, probably due to inadequate diet and environmental conditions at owners' home (AMS pers. obs.). Major advances in animal welfare would ensue if the purchase of exotic pets were to require an affiliation to accredited associations. Experienced enthusiasts could train candidate owners in how to maintain properly the species (e.g. codes of conduct for pet owners, list of options for disposed species, how to captive-bred the purchased species and to reduce the harvesting of wild stocks), and a licencing system would promote responsible maintenance if pit tags of exotic pets are associated with an owner ID. For prohibited pets held before the enforcement of new legislation (e.g. RD 216/2019), a period of possession accreditation with compulsory tagging could be enacted so that pets would not be disposed illegally in response to new regulations.

We hope this four-tier approach will reduce some drawbacks of exotic pet keeping at the expense of their benefits, including that the pet trade is often a significant component of livelihoods in rural communities (Chardonnet et al. 2002), that fish and herptile enthusiasts increase knowledge of rare species and their habitats (Chao et al. 2001; Tapley et al. 2015; Maceda-Veiga et al. 2016), and that pets contribute to 
the well-being of many people (Beck and Katcher 1996; Pasmans et al. 2017).

Acknowledgements We are grateful to two anonymous referees and the associated editor Ronaldo Sousa for their useful suggestions. We also thank to J.D. Lyons, O. DomínguezDomínguez, O. Cano-Rocabayera and S. Vargas-Amengual for inspiring discussions on the issue of unwanted exotic aquatic pets and to 'Fomento de Contratas y Construcciones' and the Galanthus Association, especially to G. Pascual-Pijoan, for providing data on Barcelona's urban lakes. Data collection and necropsies at CRARC were funded by 'Fundació Barcelona Zoo-Ajuntament de Barcelona' and additional technical support and authorizations were provided by Aïda Tarragó, Francesc Mañas and Ricard Casanovas from 'Generalitat de Catalunya'.

\section{References}

Almeida D, Ribeiro F, Leunda PM, Vilizzi L, Copp GH (2013) Effectiveness of FISK, an invasiveness screening tool for non-native freshwater fishes, to perform risk identification assessments in the Iberian Peninsula. Risk Anal 33:1404-1413

Auliya M, Altherr S, Ariano-Sanchez D, Baard EH, Brown C, Brown RM et al (2016) Trade in live reptiles, its impact on wild populations, and the role of the European market. Biol Conserv 204:103-119

Axelrod (2007) Atlas of freshwater aquarium fishes. 11th revised edn. TFH Publications,U.S.

Banha F, Gama M, Anastácio PM (2017) The effect of reproductive occurrences and human descriptors on invasive pet distribution modelling: Trachemys scripta elegans in the Iberian Peninsula. Ecol Model 360:45-52

Beck AM, Katcher AH (1996) Between pets and people: The importance of animal companionship. Purdue University Press, Purdue

Bush ER, Baker SE, Macdonald DW (2014) Global trade in exotic pets 2006-2012. Conserv Biol 28:663-676

Caiola N, Sostoa AD (2002) First record of the Asiatic cyprinid Pseudorasbora parva in the Iberian Peninsula. J Fish Biol 61:1058-1060

Chao NL, Prang G, Petry P (2001) Project Piaba-maintenance and sustainable development of ornamental fisheries in the Rio Negro basin, Amazonas, Brazil. In: Chao NL, Petry P, Prang G, Sonneschien L, Tlusty M (eds) Conservation and management of ornamental fish resources of the Rio Negro Basin, Amazonia, Brazil-Project Piaba. Chao, NL, pp 3-6

Chapman FA, Fitz-Coy SA, Thunberg EM, Adams CM (1997) United States of America trade in ornamental fish. J World Aquacult Soc 28:1-10

Chardonnet P, Clers BD, Fischer J, Gerhold R, Jori F, Lamarque F (2002) The value of wildlife. Rev Sci Tech-Off Int Epizoot 21:15-52

Chomel B, Belotto A, Meslin FX (2007) Wildlife, exotic pets, and emerging zoonoses. Emerg Infect Dis 13:6-11

Chucholl C (2013) Invaders for sale: trade and determinants of introduction of ornamental freshwater crayfish. Biol Invasions 15:125-141
Clavero M (2011) Assessing the risk of freshwater fish introductions into the Iberian Peninsula. Freshwater Biol 56:2145-2155

Colwell RK, Coddington JA (1994) Estimating terrestrial biodiversity through extrapolation. Phil Trans R Soc Lond B 345:101-118

Conrad K (2012) Trade bans: a perfect storm for poaching? Trop Conserv Sci 5:245-254

Courtenay WR Jr, Stauffer JR Jr (1990) The introduced fish problem and the aquarium fish industry. J World Aquacult Soc 21:145-159

DAISIE (2009) Handbook of alien species in Europe. Springer, Dordrecht, p 381

Demkowska-Kutrzepa M, Studzińska M, Roczeń-Karczmarz M, Tomczuk K, Abbas Z, Różański P (2018) A review of the helminths co-introduced with Trachemys scripta elegans - a threat to European native turtle health. Amphib Reptil 39:177-189

Duggan IC, Rixon CA, MacIsaac HJ (2006) Popularity and propagule pressure: determinants of introduction and establishment of aquarium fish. Biol Invasions 8:377-382

Essl F, Nehring S, Klingenstein F, Milasowszky N, Nowack C, Rabitsch W (2011) Review of risk assessment systems of IAS in Europe and introducing the German-Austrian black list information system (GABLIS). J Nat Conserv 19:339-350

EU Regulation No 338/2013 of 9 December 1996 in relation to the protection of species of animals and plants through the control of their trade

EU Regulation No 139/2013 of 7 January 2013 laying down animal health conditions for imports of certain birds into the Union and the quarantine conditions thereof Text with EEA relevance

EU Regulation No 1143/2014 of 22 October 2014 on the prevention and management of the introduction and spread of invasive alien species

Fowler AJ, Lodge DM, Hsia JF (2007) Failure of the lacey act to protect US ecosystems against animal invasions. Front Ecol Environ 5:353-359

Fox J, Weisberg S (2011) An R companion to applied regression, 2nd edn. Sage, Thousand Oaks CA

Franch N, Clavero M, Garrido M, Gaya N, López V, Pou-Rovira Q, Queral JM (2008) On the establishment and range expansion of oriental weatherfish (Misgurnus anguillicaudatus) in NE Iberian Peninsula. Biol Invasions 10:1327-1331

Fujisaki I, Hart KM, Mazzotti FJ, Rice KG, Snow S, Rochford M (2010) Risk assessment of potential invasiveness of exotic reptiles imported to south Florida. Biol Invasions 12:2585-2596

Gante HF, Moreira da Costa L, Micael J, Alves MJ (2008) First record of Barbonymus schwanenfeldii (Bleeker) in the Iberian Peninsula. J Fish Biol 72:1089-1094

García-Díaz P, Ross JV, Woolnough AP, Cassey P (2017) The illegal wildlife trade is a likely source of alien species. Conserv Let 10:690-698

Genovesi P, Carboneras C, Vila M, Walton P (2015) EU adopts innovative legislation on invasive species: a step towards a global response to biological invasions? Biol Invasions 17:1307-1311 
Gisbert E, López MA (2007) First record of a population of the exotic mummichog Fundulus heteroclitus (L., 1766) in the Mediterranean Sea basin (Ebro River delta). J Fish Biol $71: 1220-1224$

Howeth JG, Gantz CA, Angermeier PL, Frimpong EA, Hoff MH, Keller RP, Mandrak NE, Marchetti MP et al (2016) Predicting invasiveness of species in trade: climate match, trophic guild and fecundity influence establishment and impact of non-native freshwater fishes. Divers Distrib 22:148-160

Hulme PE (2015) Invasion pathways at a crossroad: policy and research challenges for managing alien species introductions. J Appl Ecol 52:1418-1424

Hulme PE, Bacher S, Kenis M, Kühn I, Pergl J, Pyšek P, Roques A, Vilà M (2017) Blurring alien introduction pathways risks losing the focus on invasive species policy. Conserv Let 10:265-266

IDESCAT (2019) Institute d'Estadística de Catalunya (in Catalan). https://www.idescat.cat/. Accessed 25 Feb 2019

Johnson ML, Speare R (2003) Survival of Batrachochytrium dendrobatidis in water: quarantine and disease control implications. Emerg Infect Dis 9:922-925

King W, Krakauer T (1966) The exotic herpetofauna of southeast Florida. Quart J Florida Acad Sci 29:144-154

Lafuente S, Bellido JB, Moraga FA, Herrera S, Yagüe A, Montalvo T, de Simó M, Caylà JA (2013) Salmonella paratyphi B and Salmonella litchfield outbreaks associated with pet turtle exposure in Spain. Enferm Infecc Microbiol Clin 31:32-35

Leprieur F, Beauchard O, Blanchet S, Oberdorff T, Brosse S (2008) Fish invasions in the world's river systems: when natural processes are blurred by human activities. PLoS Biol 6:e28

Living Planet Report (2018) https://wwf.panda.org/knowledge_ hub/all_publications/living_planet_report_2018/. Accessed 25 Feb 2019

Lockwood JL, Cassey P, Blackburn T (2005) The role of propagule pressure in explaining species invasions. T Ecol Evol 20:223-228

Luque GM, Bellard C, Bertelsmeier C, Bonnaud E, Genovesi P, Simberloff D, Courchamp F (2014) The 100th of the world's worst invasive alien species. Biol Invasions 16:981-985

Maceda-Veiga A (2013) Towards the conservation of freshwater fish: Iberian Rivers as an example of threats and management practices. Rev Fish Biol Fisher 23:1-22

Maceda-Veiga A, Escribano-Alacid J, de Sostoa A, GarcíaBerthou E (2013) The aquarium trade as a potential source of fish introductions in southwestern Europe. Biol Invasions 15:2707-2716

Maceda-Veiga A, Domínguez-Domínguez O, Escribano-Alacid J, Lyons J (2016) The aquarium hobby: can sinners become saints in freshwater fish conservation? Fish Fish 17:860-874

Masin S, Bonardi A, Padoa-Schioppa E, Bottoni L, Ficetola GF (2014) Risk of invasion by frequently traded freshwater turtles. Biol Invasions 16:217-231

Miller ML (2011) Laws, Federal and State. In: Simberloff D, Rejmánek M (eds) Encyclopedia of biological invasions, pp 430-436
OATA (2015) Ornamental aquatic association code of conduct. https://ornamentalfish.org/wp-content/uploads/2015/10/ CODE-OF-CONDUCT-FINAL-OCT-2015.pdf. Accessed 25 Feb 2019

OATA (2018). Ornamental aquatic association annual report. https://ornamentalfish.org/read-our-annual-report-2018/. Accessed 25 Feb 2019

Padilla DK, Williams SL (2004) Beyond ballast water: aquarium and ornamental trades as sources of invasive species in aquatic ecosystems. Front Ecol Environ 2:131-138

Pârâu LG, Strubbe D, Mori E, Menchetti M, Ancillotto L, Kleunen AV et al. (2016) Rose-ringed parakeet Psittacula krameri populations and numbers in Europe: a complete overview. Open Ornithol J 9(1):1-13

Pasmans F, Bogaerts S, Cunningham AA, Braeckman J, Hellebuyck T, Griffiths RA, Sparreboom M, Schmidt BR, Martel A (2017) Future of keeping pet reptiles and amphibians: towards integrating animal welfare, human health and environmental sustainability. Vet Rec 181:264

Perret N, Joly P (2002) Impacts of tattooing and PIT-tagging on survival and fecundity in the alpine newt (Triturus alpestris). Herpetologica 58:131-138

Perrings C, Dehnen-Schmutz K, Touza J, Williamson M (2005) How to manage biological invasions under globalization. T Ecol Evol 20:212-215

R Core Team (2013) R: a language and environment for statistical computing

Raghavan R, Dahanukar N, Tlusty MF, Rhyne AL, Kumar KK, Molur S, Rosser AM (2013) Uncovering an obscure trade: threatened freshwater fishes and the aquarium pet markets. Biol Conserv 164:158-169

Real Decreto 1628/2011 de 14 de noviembre, por el que se regula el listado y catálogo español de especies exóticas invasoras (in Spanish)

Real Decreto 630/2013 de 2 de agosto, por el que se regula el Catálogo español de especies exóticas invasoras (in Spanish)

Real Decreto 216/2019 de 29 de marzo, por el que se aprueba la lista de especies exóticas invasoras preocupantes para la región ultraperiférica de las islas Canarias y por el que se modifica el Real Decreto 630/2013, de 2 de agosto, por el que se regula el Catálogo español de especies exóticas invasoras (in Spanish)

Reino L, Figueira R, Beja P, Araújo MB, Capinha C, Strubbe D (2017) Networks of global bird invasion altered by regional trade ban. Sci Adv 3:e1700783

Rixon CA, Duggan IC, Bergeron NM, Ricciardi A, Macisaac HJ (2005) Invasion risks posed by the aquarium trade and live fish markets on the Laurentian Great Lakes. Biodivers Conserv 14:1365-1381

Rowan AN (1992) Shelters and pet overpopulation: a statistical black hole. Anthrozoös 5(3):140-143

Schloegel LM, Picco AM, Kilpatrick AM, Davies AJ, Hyatt AD, Daszak P (2009) Magnitude of the US trade in amphibians and presence of Batrachochytrium dendrobatidis and Ranavirus infection in imported North American bullfrogs (Rana catesbeiana). Biol Conserv 142:1420-1426

Seebens H, Blackburn TM, Dyer EE, Genovesi P, Hulme PE, Jeschke JM et al (2017) No saturation in the accumulation of alien species worldwide. Nat Commun 8:14435 
Shine C, Kettunen M, Genovesi P, Essl F, Gollasch S, Wolfgang R, Scalera R, Starfinger U, ten Brink P (2010) Assessment to Support Continued Development of the EU Strategy to Combat Invasive Alien Species. Final Report for the European Commission. Institute for European Environmental Policy (IEEP), Brussels, Belgium

Stringham OC, Lockwood JL (2018) Pet problems: biological and economic factors that influence the release of alien reptiles and amphibians by pet owners. J Appl Ecol 55:2632-2640

Tapley B, Bradfield KS, Michaels C, Bungard M (2015) Amphibian conservation and breeding programmes: do all threatened amphibians belong on the ark? Biodivers Conserv 24:2625-2646

Weyl OLF, Daga VS, Ellender BR, Vitule JRS (2016) A review of Clarias gariepinus invasions in Brazil and South Africa. J Fish Biol 89:386-402

Publisher's Note Springer Nature remains neutral with regard to jurisdictional claims in published maps and institutional affiliations. 